Article

\title{
Morphological, Leaf Nutrient, and Fruit Quality Characteristics of Diverse Tomato Cultivars under Organic Low-Input Management
}

\author{
Leangsrun Chea ${ }^{1} \oplus$, Cut Erika ${ }^{1}$, Marcel Naumann ${ }^{1}\left(\mathbb{D}\right.$, Inga Smit ${ }^{1}$, Bernd Horneburg ${ }^{2,+}$ and Elke Pawelzik ${ }^{1, *} \mathbb{D}$ \\ 1 Division Quality of Plant Products, Department of Crop Sciences, University of Goettingen, \\ 37075 Goettingen, Germany; leangsrun.chea@agr.uni-goettingen.de (L.C.); \\ cut.erika@agr.uni-goettingen.de (C.E.); marcel.naumann@agr.uni-goettingen.de (M.N.); \\ Inga.Smit@agr.uni-goettingen.de (I.S.) \\ 2 Section of Genetic Resources and Organic Plant Breeding, Department of Crop Sciences, \\ University of Goettingen, 37075 Goettingen, Germany; bernd.horneburg@uni-kassel.de \\ * Correspondence: epawelz@gwdg.de; Tel.: +49-(0)551-39-5545 \\ + Present Address: Section of Organic Plant Breeding and Agrobiodiversity, University of Kassel, \\ 37213 Witzenhausen, Germany.
}

check for updates

Citation: Chea, L.; Erika, C.; Naumann, M.; Smit, I.; Horneburg, B.; Pawelzik, E. Morphological, Leaf Nutrient, and Fruit Quality Characteristics of Diverse Tomato Cultivars under Organic Low-Input Management. Sustainability 2021, 13, 12326. https://doi.org/10.3390/ su132112326

Academic Editor: Sara Bosi

Received: 26 August 2021

Accepted: 2 November 2021

Published: 8 November 2021

Publisher's Note: MDPI stays neutral with regard to jurisdictional claims in published maps and institutional affiliations.

Copyright: (c) 2021 by the authors. Licensee MDPI, Basel, Switzerland. This article is an open access article distributed under the terms and conditions of the Creative Commons Attribution (CC BY) license (https:// creativecommons.org/licenses/by/ $4.0 /)$.

\begin{abstract}
Increasing fruit yield and quality of tomatoes under organic low-input conditions remains a challenge for producers and breeders. Therefore, it is necessary to identify superior tomato cultivars that are suitable for production and use as parents in breeding programmes. In the present study, the variations in plant morphology and fruit quality characteristics of tomato cultivars were assessed to reveal the traits associated with improved yield and fruit quality. Sixty diverse tomato cultivars were screened in 2015, and in 2016, a subset of 20 cultivars was selected for further evaluation under organic low-input conditions. The results showed high variability among cultivars in all 28 traits that were observed. Salad cultivars had lower plant growth and fruit quality (minerals, dry matter, total soluble solids, and total phenolics) by $10-70 \%$, but they displayed $10-60 \%$ higher fruit yield and leaf minerals than cocktail cultivars. Salad tomato cultivars with superior yield and harvest index were mainly derived from breeding for intensive indoor production. Cocktail cultivars with superior yield were mainly derived from organic and outdoor breeding programs. There was a trade-off between fruit yield and quality, indicating a challenge for simultaneous improvement of yield and quality. The importance of $\mathrm{Mg}$ was highlighted because of its contribution to the fruit mineral concentration and fruit quality. Cultivars superior in one trait or trait combination under organic low-input conditions were identified to be used by producers and breeders as superior cultivars to meet their production targets and breeding objectives. The importance of $\mathrm{Mg}$ provides a novel path for further research on improving soil-available $\mathrm{Mg}$ in organic tomato production to enhance fruit mineral concentration and fruit quality in general.
\end{abstract}

Keywords: cultivar; fruit yield; fruit quality; magnesium; organic low-input management; tomato

\section{Introduction}

Tomato production and consumption have grown rapidly worldwide over the past 25 years [1]. The tomato fruit is a valuable source of minerals and vitamins necessary in the human diet [2]. At the same time, the demand for organically grown tomatoes has also increased [3], driven by consumer perception that organic food is more sustainable and of better quality than food derived from conventional farming [4]. However, there is a lack of tomato cultivars bred for organic production that are both high-yielding and of superior fruit quality [5]. Tomato cultivars suitable for organic production require an adaptation strategy with more efficient nutrient uptake and utilisation under limited nutrient availability in the soils [6]. 
The diversity of cultivated tomato has increased as a result of domestication and breeding [7]. Consequently, average fruit weight varies strongly among cultivars, ranging from a few grams to one kilogram [8]. Plant morphological characteristics and fruit quality of these cultivars also differ because cultivars bred for high yield often have poor flavour and nutritional quality [9]. Tomato flavour is derived mainly from sugars, acids, and aromatic volatiles [10]. Small-fruited tomatoes may have better quality attributes but a lower yield than large-fruited tomatoes [11]. There is no universal classification of tomato regarding average fruit weight; however, Scott et al. [9] referred to tomatoes with a high sugar concentration and weighing less than $50 \mathrm{~g}$ as cocktail tomatoes. Based on this differentiation and average fruit weight recorded in the present study, we classified tomato cultivars with a weight exceeding $52 \mathrm{~g}$ per fruit as salad tomatoes. Consumers' preference for cocktail tomatoes has increased in the last decade. For example, the production of cocktail tomatoes rapidly increased from $7 \%$ of the total tomato production in the Netherlands in 2012 to $30 \%$ in 2019. In Belgium, cocktail tomato consumption was $40 \%$ compared to the total number of purchased tomatoes per household in 2019 [12]. The evaluation of salad and cocktail cultivars under organic low-input management is important for selecting superior cultivars from each fruit type for production and future breeding programmes.

The focus of tomato production, especially in Germany and the Netherlands, is on the fresh market using indeterminate cultivars that continuously produce fruit for an extended time period [13]. This requires a relatively high nutrient availability in the soil to sustain growth and yield. Recently, there has been increasing consumer demand for high-quality fruit in terms of visual appearance and flavour [13,14]. Calcium, magnesium, potassium, and phosphorus are the major minerals that make up about $8 \%$ of the dry matter in tomato fruit [15]. The concentration of these fruit minerals influences fruit colour, sweetness, and sourness [16]. Sweetness and sourness are the main determinants of tomato fruit quality $[16,17]$, making the fruit mineral concentration a key factor for consumer acceptance. Therefore, the ability of tomato cultivars to uptake and allocate these nutrients efficiently to leaves and fruit is essential. To date, the effect of tomato cultivars on fruit mineral concentration, especially their relationship with fruit yield and leaf mineral nutrients, has not been extensively studied.

In Germany, commercial tomato production covered an area of 398 hectares in 2018 [1]; about $17 \%$ of this area was used for organic cultivation [18]. The high demand for organic tomato relies heavily on imports $[19,20]$. Therefore, it is necessary to identify superior cultivars suitable for organic low-input production and for future breeding and selection programmes to genetically improve tomato fruit yield and quality. In the present study, in 2015, 60 tomato cultivars released between 1880 and 2015 with a large range of average fruit weight and, in 2016, a subset of 20 cultivars, were assessed under organic low-input conditions. These cultivars were used in the past or are still grown in present tomato production systems. Two very small-fruited cultivars, 'Rote Murmel' and 'Golden Currant' (Table 1), are usually grown as currant tomatoes with multiple shoots; they were included in the study because of their relevance in amateur outdoor production. The objective of this study was to characterise the plant growth, leaf nutrients, and fruit quality of diverse tomato cultivars in organic low-input production. We hypothesised that there is significant variation among tomato cultivars under organic low-input conditions, enabling the identification of cultivars superior for growth, yield, and fruit quality traits. The information is valuable for tomato growers to select suitable cultivars for production under low-input management and for breeders to identity traits and cultivars as potential parents for future breeding programmes. This study presented the first information on superior cultivars suitable for organic low-input production resulting from the evaluation of a diverse set of cultivars. Furthermore, the importance of $\mathrm{Mg}$, which has been neglected under organic production, in improving tomato fruit quality was highlighted. 
Table 1. Overview of tomato cultivars assessed in 2015 and 2016.

\begin{tabular}{|c|c|c|c|}
\hline \multicolumn{2}{|c|}{ Salad Cultivars ( $>52 \mathrm{~g}_{\text {fruit }}{ }^{-1}$ ) } & \multicolumn{2}{|c|}{ Cocktail Cultivars $\left(<52 \mathrm{~g}_{\text {fruit }}-1\right)$} \\
\hline Previa $\mathrm{F}_{1}$ & Red & Amoroso $F_{1}$ & Red \\
\hline Garance $\mathrm{F}_{1}$ & Red & Annamay $F_{1}$ & Red \\
\hline Green Zebra & Green-yellow & Quedlinburger Frühe Liebe & Red \\
\hline Diplom $F_{1}$ & Red & Ruthje & Red \\
\hline Cappricia $F_{1}$ & Red & König Humbert & Red \\
\hline Rougella $\mathrm{F}_{1}$ & Red & Clou & Yellow \\
\hline Sparta $\mathrm{F}_{1}$ & Red & Tastery $\mathbf{F}_{1}$ & Red \\
\hline Bocati $F_{1}$ & Red & Primabella & Red \\
\hline Phantasia $\mathrm{F}_{1}$ & Red & Sakura $F_{1}$ & Red \\
\hline Mecano $\mathrm{F}_{1}$ & Red & Black Cherry & Red-brown \\
\hline Hamlet $\mathrm{F}_{1}$ & Red & Cerise Gelb & Yellow \\
\hline Lyterno $\mathrm{F}_{1}$ & Red & Yellow Submarine & Yellow \\
\hline Nordica $F_{1}$ & Red & Zuckertraube & Red \\
\hline Moneymaker & Red & Dorada & Yellow \\
\hline Pannovy $F_{1}$ & Red & Primavera & Red \\
\hline Roterno $F_{1}$ & Red & Philovita $\mathrm{F}_{1}$ & Red \\
\hline Hildares $\mathrm{F}_{1}$ & Red & Trixi & Red \\
\hline Bonner Beste & Red & Trilly $F_{1}$ & Red \\
\hline Tica & Red & Benarys Gartenfreude & Red \\
\hline Ricca & Red & Bartelly $F_{1}$ & Red \\
\hline Aroma & Red & Golden Pearl $F_{1}$ & Yellow \\
\hline Rheinlands Ruhm & Red & Resi & Red \\
\hline Lukullus & Red & Supersweet $100 \mathrm{~F}_{1}$ & Red \\
\hline Goldene Königin & Yellow & Goldita & Orange \\
\hline Harzfeuer $F_{1}$ & Red & Sliwowidnij & Yellow \\
\hline Auriga & Orange & Rote Murmel & Red \\
\hline Haubners Vollendung & Red & Golden Currant & Yellow \\
\hline Dorenia & Red & - & - \\
\hline Roi Humbert Jaune & Yellow & - & - \\
\hline Hellfrucht & Red & - & - \\
\hline Campari $F_{1}$ & Red & - & - \\
\hline Matina & Red & - & - \\
\hline Black Plum & Red-brown & - & - \\
\hline
\end{tabular}

Cultivars shown in bold are the 20 cultivars selected from 2015 for further evaluation in 2016. The cultivars are ordered based on average fruit weight from high to low.

\section{Materials and Methods}

\subsection{Site and Climatic Description}

To assess the tomato cultivars, they were grown under low-input conditions in a temperate climate in accordance with certified organic standards [21]. Low-input conditions were defined as receiving no fertiliser application and moderate irrigation. The experiments were carried out at Reinshof Experimental Station, University of Goettingen, at $152 \mathrm{~m}$ above sea level on organic fields of Fluventic Eutrochrept soil [22] from May to October in 2015 and 2016. Temperature, relative humidity, and soil properties during the experiments were previously described in Erika et al. [23]. Additionally, available nitrogen concentrations in the soil during the growing period are shown in Table S1 in Supplementary Materials.

\subsection{Cultivars}

In 2015, 60 indeterminate tomato cultivars were used (Table 1; additional information in Table S2 in Supplementary Materials). They were chosen in close cooperation with extension services, research stations, breeders, seed companies, and the Genebank of the Leibniz Institute of Plant Genetics and Crop Plant Research Gatersleben (IPK, Seeland, Germany). The cultivars covered the entire range from old cultivars released in the 1880s to the most recently developed cultivars. For the traditional cultivars 'Goldene Königin', 'Haubners Vollendung', and 'Rheinlands Ruhm', limited knowledge could be gathered from old books and personal 
communications with Arche Noah (Schiltern, Austria) and the Genebank Gatersleben. These cultivars may have been released earlier than stated in Table S2. The years of release of 'Golden Currant', 'Rote Murmel', 'Sliwowidnij', 'Zuckertraube', 'Yellow Submarine', 'Black Cherry', and 'Black Plum' are not known with certainty because - to the best of our knowledge-these were not derived from formal breeding programmes and may have existed long before the year given in Table S2. In the case of 'Goldita', an inbred on-farm selection derived from the original hybrid cultivar was used. 'Aroma' is an advanced breeding line from organic breeder S. Wedemeyer (Kultursaat e.V., Echzell, Germany). A subset of 20 potential cultivars was selected for further evaluation in 2016.

\subsection{Experimental Layout and Crop Cultivation}

In 2015, the 60 cultivars were assessed in a randomised complete block design with eight blocks and one plant per plot. Two to three tomato seeds were sown in multipot trays QP 96 (Hermann Meyer, Rellingen, Germany) filled with the substrate 'Anzuchtsubstrat Organisch' (Kleeschulte, Rüthen, Germany), and they were reduced to single seedlings after emergence. All seedlings were potted (pot dimension $11 \times 11 \times 11 \mathrm{~cm}$ ) 20 days later in the substrate 'Fruhstorfer Bio-Aussaat- und Kräutererde' (Hawita, Vechta, Germany) and maintained in the greenhouse with a temperature of $20^{\circ} \mathrm{C}$ during the day and $18{ }^{\circ} \mathrm{C}$ during the night. During the first 20 days, the photoperiod was adjusted to $16 \mathrm{~h}$. Seven weeks after germination, the seedlings were transplanted to the field and spaced $50 \mathrm{~cm}$ apart within rows, with $100 \mathrm{~cm}$ between rows. The growing system was designed to exclude major pathogens to allow the assessment of cultivars without up-to-date field resistance. These pathogens included Phytophthora infestans (Mont.) de Bary and Cladosporium fulvum (Pers.) Link. Therefore, a well-ventilated rainout shelter with sides open to $1.8 \mathrm{~m}$ was used (Figure S1 in Supplementary Materials). Border effects were avoided by planting three border plants at either end of each row. The space between rows was covered with Plantex Gold Unkrautvlies fleece (Hermann Meyer, Rellingen Germany) for weed control. Tomato plants were trellised with strings to vertically support the vine, and the plants were fixed each week. Plants were pruned to the main shoot by removing side shoots on a weekly basis. Drip irrigation was provided through lateral polytube drip lines (John Deere, Moline, IL, USA) with $20 \mathrm{~cm}$ emitter spacing. Irrigation was moderate and based on ambient temperature, with a total amount of $150 \mathrm{~L} \mathrm{~m}^{-2}$ applied during the growing season. In 2016, the 20 selected cultivars were further assessed with two plants per plot. The crop cultivation procedures, experimental design, and management practices remained the same as in 2015.

\subsection{Sample Collection, Mineral Nutrient, and Quality Determination}

\subsubsection{Plant Morphology}

Plant height was measured at 19 weeks after planting (WAP) in 2015 and at 20 WAP in 2016. The total leaf number of each plant was counted from the first leaf above ground to the last fully developed leaf. Mature tomato fruit was harvested at two-week intervals, starting at 9 WAP in 2015 and 8 WAP in 2016. At each harvest, all mature fruit from each plant was weighed and counted, followed by the calculation of the average fruit weight, total number of tomatoes, and total yield per plant. At 20 WAP in 2015 and 21 WAP in 2016, stem and leaf biomass were determined as fresh weight. The harvest index was then calculated as the fruit yield proportion of total biomass above ground. 


\subsubsection{Macronutrient Concentrations in Leaves and Fruit}

Fully developed leaves in the middle between the apex and soil surface of each plant were sampled at 12 WAP in 2015 and at 13 WAP in 2016 to determine mineral concentrations. Fruits were randomly sampled at 13 WAP in both years to assess quality parameters. The samples were taken at the fully mature stage, as described by Liu et al. [24]. Leaf and fruit samples from the eight field replications were pooled to create four replications for further sample preparation. Leaf samples were oven-dried at $70{ }^{\circ} \mathrm{C}$ for $72 \mathrm{~h}$ and then ground with a Culatti DFH 48 (Gemini BV, Apeldoorn, the Netherlands) using a 0.5-mm sieve. Ten mature tomatoes per cocktail cultivar and three mature tomatoes per salad cultivar were selected and freeze-dried for four days using an EPSILON 2-40 (Christ, Osterode am Harz, Germany). Fruit samples were then milled with a Mixer Mill MM 400 (Retsch, Haan, Germany) to obtain a homogenous fine powder. The concentrations of phosphorus $(\mathrm{P})$, potassium $(\mathrm{K})$, calcium $(\mathrm{Ca})$, magnesium $(\mathrm{Mg})$, and sulphur $(\mathrm{S})$ in leaf and fruit samples were analysed according to Erika et al. [23]. The ground leaf samples were also used to determine nitrogen $(\mathrm{N})$ and carbon $(\mathrm{C})$ concentrations by dry combustion (Elementar, Langenselbold, Germany).

\subsubsection{Fruit Dry Matter (DM), Total Soluble Solids (TSS), and Titratable Acidity (TA)}

A subsample of fruit harvested at $13 \mathrm{WAP}$ in 2015 and 2016 was stored at $-20^{\circ} \mathrm{C}$ for further quality analysis. Ten tomatoes per cocktail cultivar and three per salad cultivar were used for the determination of dry matter, total soluble solids, and titratable acidity in accordance with the procedures described by Kanski et al. [10].

\subsubsection{Total Phenolic Concentration (TPC)}

The TPC of tomato fruit was determined using a Folin-Ciocalteu assay [25]. A total of $250 \mathrm{mg}$ of the freeze-dried sample was homogenised twice with $5 \mathrm{~mL} 80 \%$ ethanol and centrifuged for $10 \mathrm{~min}$ at $5000 \times \mathrm{g}$. The supernatant from the two steps was pooled and filled, up to $10 \mathrm{~mL}$, with $80 \%$ ethanol. For measurement, $500 \mu \mathrm{L}$ of the extract was suspended with $2.4 \mathrm{~mL}$ water, $1 \mathrm{~mL} 0.5 \mathrm{M} \mathrm{NaOH}$, and $100 \mu \mathrm{L}$ Folin reagent. The mixture was incubated at $37^{\circ} \mathrm{C}$ for $15 \mathrm{~min}$, and absorbance was measured at $736 \mathrm{~nm}$ in an HP 8453 UV-Vis spectrophotometer (Hewlett Packard, Böblingen, Germany) against blanks. Finally, the TPC was calculated based on the gallic acid standard calibration curve and expressed as milligrams of gallic acid equivalents per $100 \mathrm{~g}$ fresh matter (mg GAE $100 \mathrm{~g}^{-1} \mathrm{FM}$ ).

\subsubsection{Fruit Colour}

Eight and ten mature tomatoes of cocktail and salad cultivars, respectively, harvested 13 WAP in both years, were measured for fruit colour using a Minolta Chroma meter CR-400 (Konica Minolta Optics, Tokyo, Japan), in accordance with Kanski et al. [10].

\subsection{Statistical Analyses}

The descriptive statistics of each measured trait were calculated. The effects of cultivar and year were analysed by analysis of variance. Tukey's honestly significant difference (HSD) was calculated at $p<0.05$ as a post hoc test. Pearson's correlation was employed to investigate trait associations. The calculation and statistical analyses were conducted with Statistix (Version 8.0, Analytical Software, Tallahassee, FL, USA). 


\section{Results}

\subsection{Variation of 60 Cultivars}

Sixty tomato cultivars were grown in 2015 to assess their performance in growth, leaf mineral concentration, yield, and fruit quality under organic low-input management. A total of 28 parameters were investigated. Significant differences among cultivars were observed for all parameters (Table S3 in Supplementary Materials). Plant agronomic traits, such as leaf and stem biomass, fruit yield, average fruit weight, and fruit number, had a high coefficient of variation (CV), ranging from 33.4 to $68.7 \%$. Traits associated with fruit quality characteristics (DM, TSS, TA, and TPC) also obtained medium to high CVs (14.7 to $29.5 \%$ ). The CVs of other traits related to minerals in leaves and fruit were classified as low to high (1.8 to $27.4 \%)$. Fruit colours varied and ranged from light green to red $\left(\mathrm{a}^{*} ;-11.0\right.$ to 27.4 ) and yellow at different pigment intensities ( $\mathrm{b}^{*} ; 9.5$ to 45.7$)$ (Table 1 and Table S3). These results indicate a high genetic diversity among the 60 assessed tomato cultivars.

Considering the high diversity of average fruit weight (5.5 to $\left.171.5 \mathrm{~g} \mathrm{fruit}^{-1}\right)$, the cultivars were classified, based on average fruit weight, into two groups: salad $\left(>52 \mathrm{~g}^{\text {fruit }}{ }^{-1}\right)$ and cocktail $\left(<52 \mathrm{~g}\right.$ fruit $\left.^{-1}\right)$. The results of analysis of variance within the two groups are shown in Table S4 in Supplementary Materials. In salad cultivars, the year of release correlated positively with plant height; fruit yield; harvest index; and leaf C, Ca, and S concentrations (Figure S2 in Supplementary Materials). A high variation of leaf and stem biomass, average fruit weight, and fruit yield enabled the selection of cultivars with superior performance in plant morphology and yield (Figure 1A). Fruit TSS and TA were also included in the selection criteria (Figure 1B) because they were among the most important traits for improving tomato fruit quality to gain consumer acceptance [17]. Presumably, variation in the traits used as selection criteria could be reflected in the variability of other traits on account of trait correlations (Figure S3 in Supplementary Materials). Ultimately, eight salad and twelve cocktail cultivars with outstanding performance in one trait or a combination of traits were selected for further evaluation in 2016 (Figures 1 and 2).

\subsection{Morphological and Fruit Quality Characteristics of the 20 Selected Cultivars}

The selected 20 cultivars (Table 1; shown in bold) were grown in 2016 to further characterise plant morphology, yield, and fruit quality and to identify the best performing ones for fruit yield and quality in organic low-input management. The dataset for evaluation of these 20 cultivars was obtained from 2015 and 2016. Although cultivars grown in 2016 had lower stem and leaf biomass than those in 2015, the fruit yield of cocktail cultivars in 2016 was 13\% higher than that in 2015. Furthermore, an unpaired t-test was used to compare the performance of salad and cocktail cultivars. In both the years, salad cultivars displayed lower plant height, leaf number, leaf and stem biomass, fruit number, fruit mineral concentrations ( $\mathrm{P}, \mathrm{S}, \mathrm{Mg}$, and $\mathrm{K}$ ), and fruit quality characteristics (DM, TSS, and TPC) by $10-70 \%$, but they had higher fruit yield and leaf mineral concentrations $(\mathrm{S}, \mathrm{Mg}$, and $\mathrm{Ca}$ ) by $10-60 \%$ compared to cocktail cultivars (Figure S4 in Supplementary Materials). Because of these differences, the results were analysed separately for each group. For cocktail cultivars, analysis of variance revealed a significant interaction between cultivar and year in plant morphological characteristics and fruit minerals. However, a significant interaction was not clearly observed in salad cultivars (Tables 2 and 3). 


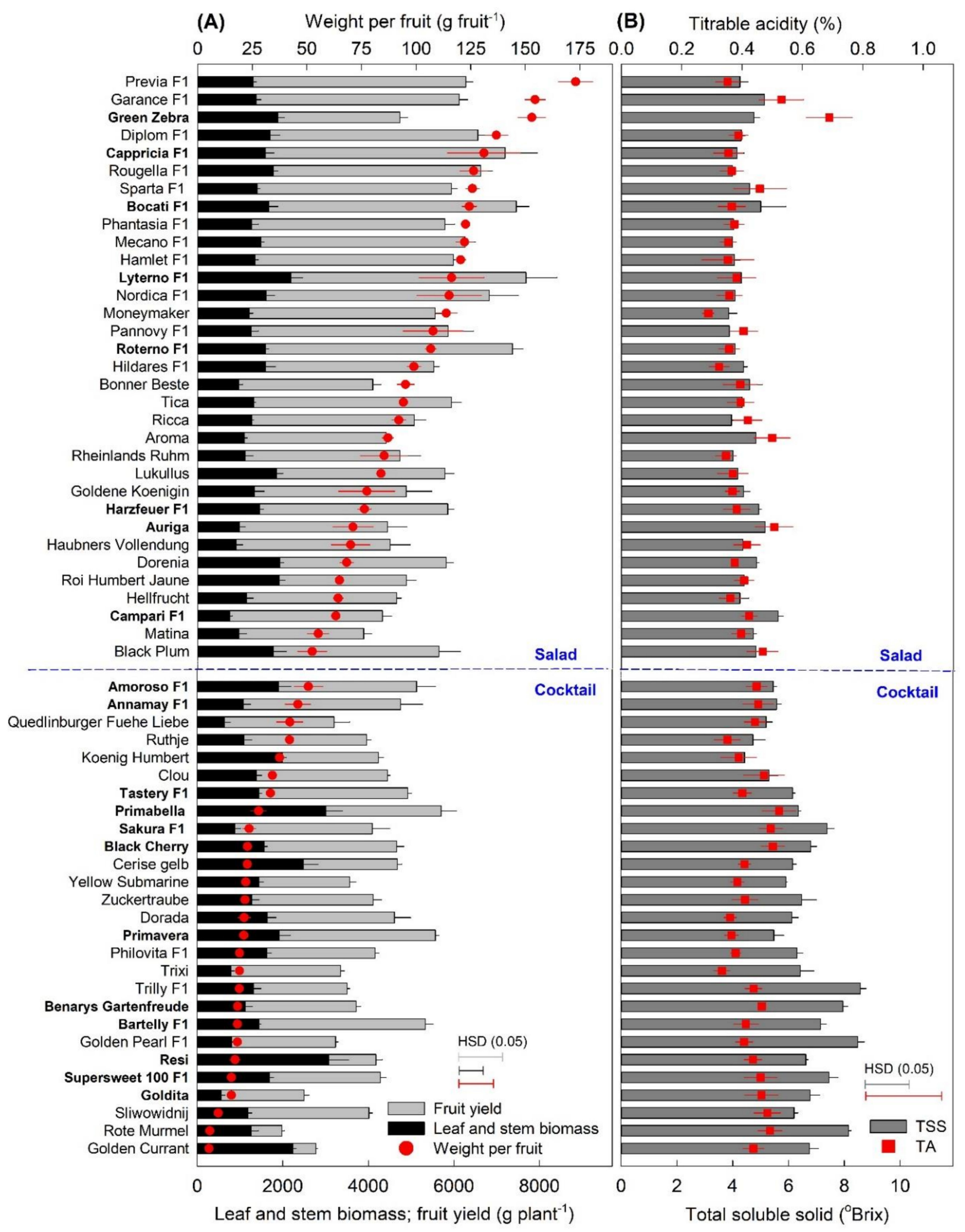

Figure 1. (A) Leaf and stem biomass, fruit yield, and average fruit weight and (B) fruit total soluble solid (TSS) and titratable acidity (TA) of 60 tomato cultivars grown in 2015. Error bars indicate the standard error of the mean. Cultivars shown in bold are the cultivars selected from 2015 for further evaluation in 2016. Cultivar names 'Goldene Koenigin', 'Quedlinburger Fruehe Liebe', and 'Koenig Humbert' were written as 'Goldene Königin', 'Quedlinburger Frühe Liebe', and 'König Humbert', respectively. The cultivars are ordered based on average fruit weight. Error bars indicate the critical value for comparison of each trait among the 60 cultivars by Tukey's HSD test at $p<0.05$. 


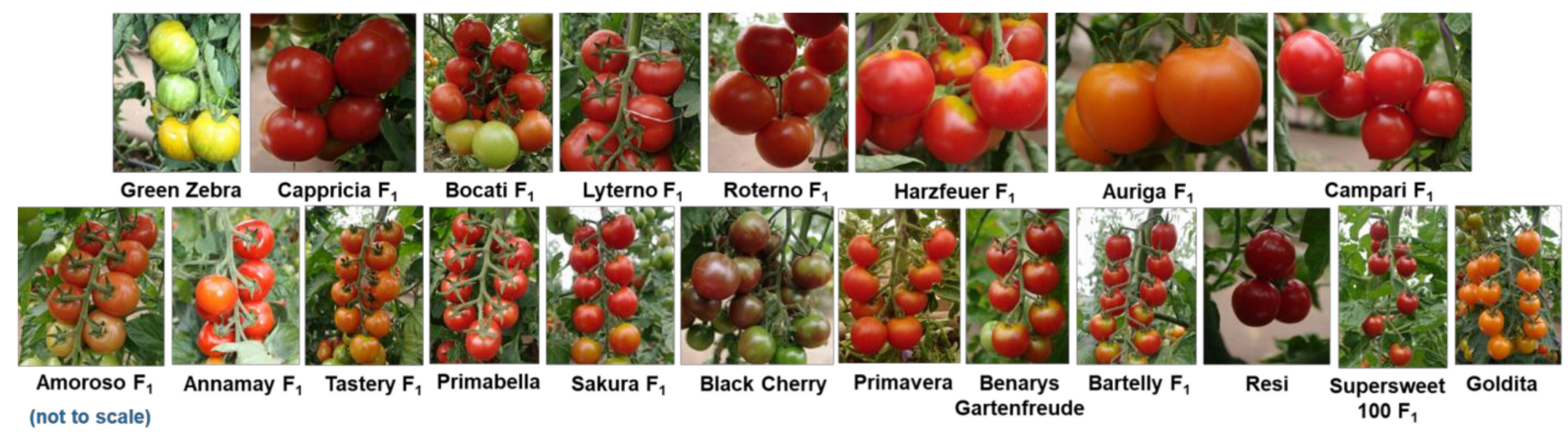

Figure 2. Fruit colour phenotypes of 20 tomato cultivars consisting of eight salad and twelve cocktail cultivars selected in 2015 for further evaluation in 2016 (Photos: L. Chea and J. Lange).

Table 2. Plant morphological and agronomic characteristics of eight salad and twelve cocktail tomato cultivars grown in 2015 and 2016.

\begin{tabular}{|c|c|c|c|c|c|c|c|c|c|c|c|c|c|c|}
\hline \multirow{2}{*}{ Cultivar } & \multirow{2}{*}{$\begin{array}{l}\mathrm{PH} \\
(\mathrm{cm})\end{array}$} & \multirow{2}{*}{$\begin{array}{c}\text { LN } \\
\left.\text { (Plant }^{-1}\right)\end{array}$} & \multirow{2}{*}{$\begin{array}{c}\text { LSB } \\
\left.\text { (g Plant }^{-1}\right)\end{array}$} & \multirow{2}{*}{$\begin{array}{c}\text { FY } \\
\left.\text { (g Plant }^{-1}\right)\end{array}$} & \multirow{2}{*}{$\begin{array}{c}\text { AFW } \\
\text { (g Fruit }^{-1} \text { ) }\end{array}$} & \multirow{2}{*}{$\begin{array}{c}\text { FN } \\
\left.\text { (Plant }^{-1}\right)\end{array}$} & \multirow[t]{2}{*}{ HI } & \multicolumn{7}{|c|}{ Leaf Minerals (mg g $\left.{ }^{-1} \mathrm{DM}\right)$} \\
\hline & & & & & & & & $\mathrm{C}$ & $\mathbf{N}$ & $\mathbf{P}$ & $K^{00}$ & $\mathrm{Mg}$ & $\mathrm{Ca}$ & $\mathrm{S}$ \\
\hline \multicolumn{15}{|l|}{ Salad cultivar (S) } \\
\hline Green Zebra & 216.3 & 42 & 1520 & 3212 & 145.7 & 22 & 0.76 & 387.1 & 28.1 & 2.0 & 25.8 & 5.2 & 47.8 & 6.0 \\
\hline Cappricia $\mathrm{F}_{1}$ & 284.0 & 49 & 1321 & 5724 & 127.3 & 45 & 0.86 & 382.1 & 24.4 & 1.6 & 22.3 & 3.3 & 59.0 & 7.5 \\
\hline Bocati $F_{1}$ & 284.4 & 47 & 1408 & 5680 & 119.7 & 48 & 0.85 & 384.0 & 23.9 & 1.7 & 21.5 & 2.9 & 58.8 & 6.8 \\
\hline Lyterno $F_{1}$ & 308.6 & 51 & 1718 & 5738 & 115.2 & 50 & 0.83 & 383.7 & 23.4 & 1.6 & 23.5 & 3.1 & 56.3 & 6.3 \\
\hline Roterno $\mathrm{F}_{1}$ & 283.8 & 49 & 1286 & 5824 & 105.4 & 56 & 0.86 & 381.8 & 24.3 & 1.5 & 22.4 & 3.5 & 56.4 & 6.8 \\
\hline Harzfeuer $F_{1}$ & 231.8 & 46 & 1258 & 4031 & 74.1 & 54 & 0.81 & 391.0 & 22.2 & 1.4 & 17.8 & 3.5 & 47.6 & 5.4 \\
\hline Auriga & 223.6 & 45 & 865 & 3498 & 73.8 & 48 & 0.85 & 384.4 & 24.9 & 1.7 & 19.2 & 4.2 & 56.8 & 6.6 \\
\hline Campari $\mathrm{F}_{1}$ & 248.3 & 45 & 707 & 3733 & 62.8 & 59 & 0.87 & 386.1 & 23.4 & 1.6 & 19.8 & 3.3 & 57.1 & 6.7 \\
\hline CV $(\%)$ & 13.2 & 5.8 & 26.2 & 24.7 & 28.8 & 23.7 & 4.3 & 0.8 & 7.2 & 11.1 & 11.9 & 8.4 & 20.6 & 9.7 \\
\hline Significance & $* * *$ & $* * *$ & $* * *$ & $* * *$ & $* * *$ & $* * *$ & $* * *$ & $\mathrm{~ns}$ & $* * *$ & $* * *$ & $* * *$ & $* * *$ & $* * *$ & $* *$ \\
\hline HSD (0.05) & 21.6 & 4 & 245 & 568 & 9.8 & 5 & 0.03 & 10.4 & 3.1 & 0.2 & 2.7 & 0.8 & 7.9 & 1.4 \\
\hline \multicolumn{15}{|l|}{ Years (Y) } \\
\hline 2015 & 266.9 & 36 & 1498 & 4611 & 105.2 & 47 & 0.82 & 387.2 & 23.5 & 1.7 & 26.1 & 3.7 & 52.3 & 6.1 \\
\hline 2016 & 254.7 & 52 & 1034 & 4732 & 100.8 & 49 & 0.85 & 382.8 & 25.2 & 1.6 & 17.0 & 3.6 & 57.7 & 6.9 \\
\hline Significance & $* *$ & $* * *$ & $* * *$ & ns & $* *$ & $*$ & $* * *$ & * & $* *$ & $* * *$ & $* * *$ & ns & $* *$ & $* * *$ \\
\hline Interaction (SxY) & $* *$ & $*$ & $* * *$ & ns & ns & * & $* *$ & ns & ns & $* *$ & ns & $*$ & ns & ns \\
\hline \multicolumn{15}{|c|}{ Cocktail cultivar (C) } \\
\hline Amoroso $\mathrm{F}_{1}$ & 266.9 & 49 & 1651 & 3539 & 49.3 & 73 & 0.77 & 393.1 & 23.6 & 1.6 & 21.6 & 3.5 & 47.9 & 5.5 \\
\hline Annamay $F_{1}$ & 303.5 & 53 & 974 & 3902 & 47.1 & 83 & 0.84 & 383.3 & 21.9 & 1.6 & 21.6 & 3.5 & 59.5 & 6.6 \\
\hline Tastery $\mathrm{F}_{1}$ & 307.8 & 51 & 1289 & 3598 & 33.0 & 110 & 0.79 & 394.7 & 26.5 & 1.7 & 25.2 & 3.2 & 48.9 & 6.5 \\
\hline Primabella & 320.0 & 62 & 2583 & 3088 & 27.9 & 111 & 0.62 & 402.9 & 24.8 & 1.9 & 24.7 & 3.1 & 39.4 & 4.5 \\
\hline Sakura $F_{1}$ & 299.8 & 56 & 822 & 3368 & 23.9 & 141 & 0.84 & 384.0 & 23.0 & 1.5 & 19.6 & 3.3 & 63.2 & 6.0 \\
\hline Black Cherry & 325.9 & 49 & 1394 & 3162 & 24.1 & 133 & 0.76 & 394.4 & 26.2 & 1.7 & 18.9 & 4.4 & 51.6 & 5.2 \\
\hline Primavera & 336.4 & 59 & 1655 & 3838 & 21.4 & 181 & 0.74 & 386.8 & 24.6 & 1.7 & 26.5 & 3.0 & 53.4 & 5.3 \\
\hline $\begin{array}{l}\text { Benarys } \\
\text { Gartenfreude }\end{array}$ & 256.1 & 48 & 1048 & 2816 & 18.8 & 150 & 0.78 & 382.7 & 21.0 & 1.5 & 17.4 & 2.9 & 61.7 & 5.2 \\
\hline Bartelly $F_{1}$ & 321.6 & 53 & 1295 & 4076 & 16.6 & 252 & 0.81 & 386.5 & 25.8 & 1.7 & 25.1 & 4.2 & 58.3 & 6.0 \\
\hline Resi & 346.0 & 59 & 2578 & 1186 & 18.6 & 64 & 0.37 & 398.1 & 25.0 & 1.8 & 21.5 & 4.2 & 40.9 & 5.2 \\
\hline Supersweet $100 \mathrm{~F}_{1}$ & 332.8 & 58 & 1593 & 2905 & 14.7 & 202 & 0.71 & 392.1 & 23.7 & 1.6 & 23.8 & 3.1 & 47.9 & 5.2 \\
\hline Goldita & 225.6 & 53 & 563 & 2115 & 16.3 & 129 & 0.83 & 401.2 & 23.7 & 1.4 & 21.2 & 3.1 & 46.8 & 4.5 \\
\hline CV $(\%)$ & 12.0 & 8.4 & 42.9 & 26.2 & 44.8 & 40.7 & 17.8 & 1.8 & 6.9 & 8.7 & 12.6 & 15.1 & 14.8 & 12.5 \\
\hline Significance & $* * *$ & $* * *$ & $* * *$ & $* * *$ & $* * *$ & $* * *$ & $* * *$ & $* * *$ & $* * *$ & $* * *$ & $* * *$ & $* * *$ & $* * *$ & $* * *$ \\
\hline HSD (0.05) & 30.1 & 5 & 417 & 485 & 2.9 & 25 & 0.05 & 8.5 & 3.2 & 0.2 & 4.1 & 0.7 & 7.9 & 1.1 \\
\hline \multicolumn{15}{|l|}{ Years (Y) } \\
\hline 2015 & 297.8 & 42 & 1621 & 2938 & 25.6 & 127 & 0.72 & 387.0 & 23.6 & 1.7 & 26.4 & 3.9 & 55.2 & 5.6 \\
\hline 2016 & 308.9 & 60 & 1287 & 3323 & 25.9 & 146 & 0.76 & 396.3 & 24.8 & 1.6 & 18.1 & 3.0 & 48.1 & 5.3 \\
\hline Significance & $* *$ & $* * *$ & $* * *$ & $* * *$ & ns & $* * *$ & $* * *$ & $* * *$ & $* * *$ & $* * *$ & $* * *$ & $* * *$ & $* * *$ & $*$ \\
\hline Interaction (CXY) & $* * *$ & $* * *$ & $* * *$ & $* * *$ & $* * *$ & $* * *$ & $* * *$ & ns & $* * *$ & ns & $*$ & ns & ns & ns \\
\hline
\end{tabular}

PH = plant height; LN = leaf number; LSB = leaf and stem biomass; FY = fruit yield; AFW = average fruit weight, FN = fruit number; $\mathrm{HI}=$ harvest index; $\mathrm{DM}=$ dry matter; $\mathrm{CV}=$ coefficient of variation; ns indicates a nonsignificant difference; ${ }^{*}{ }^{* *}$ and ${ }^{* * *}$ indicate significance differences of each factor and interaction at $p<0.05, p<0.01$ and $p<0.001$, respectively; $\operatorname{HSD}(0.05)=\operatorname{critical}$ value for comparisons by Tukey's honestly significant difference (HSD) test at $p<0.05$. The cultivars are ordered based on average fruit weight. 
Table 3. Fruit quality characteristics of eight salad and twelve cocktail cultivars grown in 2015 and 2016.

\begin{tabular}{|c|c|c|c|c|c|c|c|c|c|c|c|c|c|c|}
\hline \multirow[b]{2}{*}{ Cultivar } & \multicolumn{5}{|c|}{ Fruit Minerals (mg $\left.100 \mathrm{~g}^{-1} \mathrm{FW}\right)$} & \multirow{2}{*}{$\begin{array}{l}\text { DM } \\
(\%)\end{array}$} & \multirow{2}{*}{$\begin{array}{l}\text { TSS } \\
\left({ }^{\circ} \text { Brix }\right)\end{array}$} & \multirow{2}{*}{$\begin{array}{l}\text { TA } \\
(\%)\end{array}$} & \multirow{2}{*}{$\begin{array}{c}\text { TPC } \\
\left(m g \text { GAE } 100 \mathrm{~g}^{-1}\right) \text { FW) }\end{array}$} & \multicolumn{5}{|c|}{ Fruit Colour } \\
\hline & $\mathbf{P}^{\#}$ & $\mathbf{K}^{\#}$ & $\mathrm{Mg}^{\#}$ & Ca & $S$ & & & & & $\mathbf{L}^{*}$ & $a^{*}$ & $b^{*}$ & $C^{*}$ & ${ }^{\circ} \mathbf{h}$ \\
\hline \multicolumn{15}{|l|}{ Salad cultivar (S) } \\
\hline Green Zebra & 30.7 & 297.4 & 14.2 & 13.2 & 15.6 & 5.7 & 5.1 & 0.65 & 139.2 & 58.9 & -10.7 & 37.0 & 41.9 & 105.4 \\
\hline Cappricia $\mathrm{F}_{1}$ & 25.9 & 246.9 & 8.5 & 15.3 & 13.0 & 5.6 & 4.6 & 0.35 & 109.0 & 53.4 & 22.5 & 28.4 & 39.6 & 54.0 \\
\hline Bocati $F_{1}$ & 21.4 & 212.4 & 8.3 & 12.4 & 11.0 & 5.2 & 5.1 & 0.38 & 105.2 & 53.1 & 24.4 & 28.0 & 40.1 & 51.2 \\
\hline Lyterno $\mathrm{F}_{1}$ & 26.2 & 243.7 & 9.2 & 15.2 & 13.5 & 5.9 & 4.6 & 0.38 & 131.8 & 52.8 & 20.0 & 25.6 & 35.8 & 54.4 \\
\hline Roterno $\mathrm{F}_{1}$ & 24.4 & 237.9 & 9.4 & 14.5 & 13.2 & 5.5 & 4.5 & 0.37 & 119.3 & 53.3 & 21.6 & 27.8 & 38.3 & 54.4 \\
\hline Harzfeuer $F_{1}$ & 26.8 & 303.2 & 10.9 & 11.7 & 14.4 & 6.8 & 5.5 & 0.42 & 143.4 & 50.4 & 19.5 & 23.8 & 34.1 & 53.4 \\
\hline Auriga & 29.0 & 299.0 & 13.5 & 8.0 & 14.7 & 6.9 & 5.5 & 0.53 & 160.8 & 61.5 & 13.5 & 42.8 & 47.5 & 73.1 \\
\hline Campari $\mathrm{F}_{1}$ & 30.1 & 293.9 & 11.9 & 13.7 & 15.0 & 6.9 & 6.1 & 0.47 & 158.1 & 50.2 & 17.0 & 23.1 & 31.9 & 56.4 \\
\hline CV $(\%)$ & 11.6 & 13.3 & 18.5 & 21.2 & 10.6 & 11.6 & 10.6 & 23.4 & 15.7 & 7.3 & 70.6 & 23.2 & 12.6 & 29.5 \\
\hline Significance & $* * *$ & $* * *$ & $* * *$ & $* * *$ & $* * *$ & $* * *$ & $* * *$ & $* * *$ & $* * *$ & $* * *$ & $* * *$ & $* * *$ & $* * *$ & $* * *$ \\
\hline $\operatorname{HSD}(0.05)$ & 5.8 & 56.5 & 2.2 & 4.6 & 2.8 & 1.1 & 1.0 & 0.08 & 21.7 & 1.9 & 2.0 & 2.8 & 3.3 & 6.4 \\
\hline \multicolumn{15}{|l|}{ Years (Y) } \\
\hline 2015 & 28.7 & 280.1 & 10.6 & 13.2 & 14.9 & 5.8 & 4.7 & 0.43 & 177.0 & 54.1 & 18.2 & 30.4 & 37.1 & 58.8 \\
\hline 2016 & 25.0 & 254.1 & 10.9 & 12.8 & 12.8 & 6.3 & 5.5 & 0.46 & 93.0 & 54.2 & 14.5 & 28.6 & 39.9 & 65.5 \\
\hline Significance & $* * *$ & $* *$ & ns & ns & $* * *$ & $*$ & $* * *$ & ns & $* * *$ & ns & $* * *$ & $* *$ & ns & $* *$ \\
\hline Interaction (SxY) & ns & ns & ns & $* *$ & ns & ns & ns & ns & ns & ns & ns & ns & ns & ns \\
\hline \multicolumn{15}{|l|}{ Cocktail cultivar (C) } \\
\hline Amoroso $\mathrm{F}_{1}$ & 27.8 & 233.8 & 9.8 & 12.9 & 13.9 & 7.4 & 6.0 & 0.49 & 151.7 & 49.6 & 13.3 & 20.4 & 27.9 & 59.6 \\
\hline Annamay $\mathrm{F}_{1}$ & 31.3 & 314.2 & 13.4 & 15.0 & 15.4 & 7.1 & 6.2 & 0.50 & 176.8 & 50.8 & 17.3 & 22.7 & 32.0 & 54.9 \\
\hline Tastery $\mathrm{F}_{1}$ & 31.5 & 266.9 & 11.6 & 13.7 & 15.1 & 8.3 & 6.7 & 0.39 & 167.8 & 51.4 & 13.1 & 23.1 & 30.1 & 62.5 \\
\hline Primabella & 38.5 & 339.3 & 14.4 & 13.4 & 19.1 & 8.3 & 6.8 & 0.54 & 203.1 & 50.4 & 19.9 & 23.1 & 33.7 & 51.6 \\
\hline Sakura $F_{1}$ & 31.3 & 297.6 & 12.9 & 12.4 & 14.6 & 9.0 & 7.7 & 0.53 & 200.7 & 49.3 & 13.2 & 21.3 & 28.5 & 60.1 \\
\hline Black Cherry & 27.4 & 253.8 & 11.6 & 11.9 & 14.9 & 7.6 & 6.9 & 0.53 & 172.2 & 47.9 & 4.8 & 9.8 & 16.1 & 66.5 \\
\hline Primavera & 30.5 & 273.2 & 10.6 & 13.1 & 16.4 & 7.4 & 6.2 & 0.38 & 188.4 & 49.6 & 12.5 & 21.0 & 28.2 & 61.5 \\
\hline $\begin{array}{l}\text { Benarys } \\
\text { Gartenfreude }\end{array}$ & 36.6 & 334.3 & 12.8 & 9.6 & 18.0 & 10.4 & 8.3 & 0.55 & 177.6 & 50.0 & 13.9 & 20.5 & 28.5 & 58.6 \\
\hline Bartelly F1 & 39.0 & 320.9 & 13.5 & 16.9 & 18.8 & 8.5 & 7.7 & 0.45 & 211.8 & 49.9 & 14.0 & 20.2 & 28.2 & 57.6 \\
\hline Resi & 48.2 & 360.6 & 16.6 & 19.4 & 21.7 & 8.0 & 6.9 & 0.47 & 205.4 & 50.5 & 18.5 & 20.9 & 31.6 & 51.0 \\
\hline Supersweet $100 \mathrm{~F}_{1}$ & 42.7 & 344.8 & 15.5 & 9.7 & 19.9 & 10.1 & 8.2 & 0.54 & 224.2 & 49.7 & 15.9 & 21.4 & 30.1 & 55.7 \\
\hline Goldita & 33.6 & 310.6 & 13.2 & 17.7 & 20.1 & 9.5 & 7.4 & 0.51 & 275.6 & 56.2 & 7.0 & 31.3 & 35.5 & 78.3 \\
\hline $\mathrm{CV}(\%)$ & 18.1 & 13.0 & 21.7 & 14.9 & 15.0 & 12.7 & 10.9 & 11.6 & 16.6 & 4.0 & 31.7 & 22.0 & 16.4 & 12.2 \\
\hline Significance & $* * *$ & $* * *$ & $* * *$ & $* * *$ & $* * *$ & $* * *$ & $* * *$ & $* * *$ & $* * *$ & $* * *$ & $* * *$ & $* * *$ & $* * *$ & $* * *$ \\
\hline HSD (0.05) & 8.4 & 70.7 & 3.3 & 5.4 & 4.6 & 1.7 & 0.6 & 0.08 & 33.0 & 1.2 & 2.6 & 2.3 & 3.4 & 5.9 \\
\hline \multicolumn{15}{|l|}{ Years (Y) } \\
\hline 2015 & 35.0 & 297.5 & 12.2 & 14.3 & 17.5 & 8.3 & 6.6 & 0.45 & 250.3 & 50.2 & 14.5 & 22.0 & 26.8 & 56.3 \\
\hline 2016 & 34.7 & 310.9 & 13.8 & 13.4 & 17.2 & 8.7 & 7.6 & 0.53 & 142.3 & 50.7 & 12.7 & 20.6 & 31.6 & 63.4 \\
\hline Significance & ns & $* * *$ & $* * *$ & ns & ns & ns & $* * *$ & $* * *$ & $* * *$ & $* *$ & $* * *$ & $* * *$ & $*$ & $* * *$ \\
\hline Interaction (CXY) & $*$ & $* *$ & $* *$ & $*$ & $*$ & ns & ns & ns & $* *$ & $* * *$ & $* * *$ & $* * *$ & ns & ns \\
\hline
\end{tabular}

$\mathrm{DM}=$ dry matter; TSS = total soluble solid; TA = titratable acidity; TPC = total phenolic concentration; GAE $=$ gallic acid equivalent; $\mathrm{FW}=$ fresh weight; $\mathrm{CV}=$ coefficient of variation; ns indicates a nonsignificant difference; ${ }^{*},{ }^{* *}$ and ${ }^{* * *}$ indicate a significance difference of each factor and interaction at $p<0.05 p<0.01$, and $p<0.001$ respectively; $\operatorname{HSD}(0.05)=$ critical value for comparisons by Tukey's honestly significant difference (HSD) test at $p<0.05$; ${ }^{\#}$ data taken from Erika et al. [23]. The cultivars are ordered based on average fruit weight.

\subsubsection{Plant Morphological Characteristics}

Plant height, leaf number, leaf and stem biomass, fruit yield, average fruit weight, fruit number, and harvest index differed significantly within salad and cocktail cultivars (Table 2). In salad cultivars, plant height, leaf number, and leaf and stem biomass reached $308.6 \mathrm{~cm}, 51$ plant $^{-1}$, and 1718 g plant $^{-1}$, respectively, in 'Lyterno $\mathrm{F}_{1}$ '. However, 'Roterno $\mathrm{F}_{1}{ }^{\prime}$ displayed the highest fruit yield (5824 g plant ${ }^{-1}$ ) and a high harvest index (0.86). In cocktail cultivars, the tallest plant height $(346.0 \mathrm{~cm})$ was observed in 'Resi', and the highest leaf number $\left(62\right.$ plant $\left.^{-1}\right)$ and leaf and stem biomass $\left(2583 \mathrm{~g} \mathrm{plant}^{-1}\right)$ were detected in 'Primabella'. 'Bartelly $\mathrm{F}_{1}$ ' had the highest fruit yield (4076 $\mathrm{g} \mathrm{plant}^{-1}$ ) and fruit number (252 plant $^{-1}$ ). 'Sakura $\mathrm{F}_{1}$ ' and 'Annamay $\mathrm{F}_{1}$ ' obtained the highest harvest index (0.84). These results suggested that in both salad and cocktail cultivars, improved plant growth did not guarantee higher fruit yield.

\subsubsection{Leaf Macronutrient Concentration}

Mineral analyses in leaves showed that the salad cultivars with superior growth and fruit yield mentioned above had leaf macronutrient concentrations within average ranges (Table 2). Nevertheless, leaves of 'Green Zebra' contained the highest N, P, K, and $\mathrm{Mg}$ concentrations, which were 28.1, 2.0, 25.8, and $5.2 \mathrm{mg} \mathrm{g}^{-1}$, respectively. The highest leaf $\mathrm{Ca}$ and $\mathrm{S}$ concentrations were observed in 'Cappricia $\mathrm{F}_{1}$ '. Among cocktail cultivars, 'Resi', which had the highest leaf and stem biomass, showed leaf concentrations of 398.1, $25.0,1.8$, and $4.2 \mathrm{mg} \mathrm{g}^{-1}$ for $\mathrm{C}, \mathrm{N}, \mathrm{P}$, and $\mathrm{Mg}$, respectively, which were not significantly different from the highest values (Table 2). Moreover, leaf $\mathrm{N}, \mathrm{P}, \mathrm{K}, \mathrm{Ca}, \mathrm{Mg}$, and $\mathrm{S}$ of 
the cultivar with the highest fruit yield ('Bartelly $\mathrm{F}_{1}$ ') were 25.8, 1.7, 25.1, 4.2, 58.3, and $6.0 \mathrm{mg} \mathrm{g}^{-1}$, respectively, and not significantly different from the highest values. Therefore, leaf macronutrient concentration could contribute to enhanced plant biomass and fruit yield of cocktail cultivars, but this trend was not evident in salad cultivars.

\subsubsection{Fruit Minerals}

As minerals are essential for consumers' health, fruit macronutrient concentrations were also characterised. Mineral concentrations in the fruit of salad and cocktail cultivars were highly variable, in which their CVs ranged from 10.6 to $21.2 \%$ and 13.0 to $21.7 \%$, respectively (Table 3). The relationships between leaf and fruit minerals were further determined by Pearson's correlation analysis. We found a significant correlation between leaf and fruit Mg within salad cultivars (Figure 3A). 'Auriga' and 'Green Zebra' were outstanding cultivars for $\mathrm{Mg}$ concentration in both leaves and fruit. In cocktail cultivars, 'Resi' had relatively high Mg concentration in fruits and leaves (Figure 3A). No other significant correlation between leaf and fruit minerals was detected.

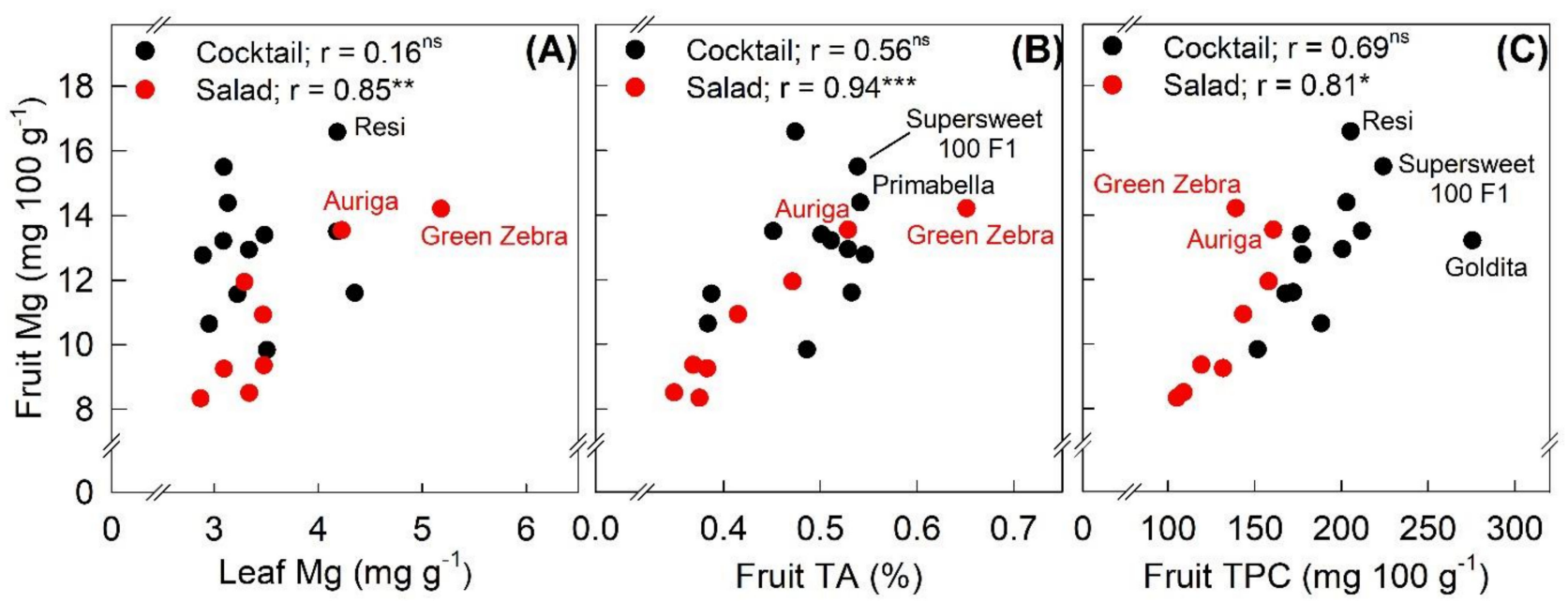

Figure 3. Relationship between fruit magnesium $(\mathrm{Mg})$ and (A) leaf $\mathrm{Mg}$, (B) fruit titratable acidity (TA), and (C) fruit total phenolic concentration (TPC) of salad $(n=8)$ and cocktail $(n=12)$ cultivars grown in 2015 and 2016. ns, ${ }^{*},{ }^{* *}$ and ${ }^{* * *}$ indicate a nonsignificant and significant correlation at $p<0.05, p<0.01$ and $p<0.001$ respectively. Cultivars mentioned in the figures are cultivars with promising performance in trait combinations.

\subsubsection{Fruit Quality Characteristics and Fruit Colour}

The fruit DM, TSS, TA, TPC, and colour of salad and cocktail cultivars were measured because they are important parameters that determine tomato fruit quality and consumer acceptance. High variability was observed for each trait; the CVs ranged from 7.3 to $70.6 \%$ and 4.0 to $31.7 \%$ in salad and cocktail cultivars, respectively. Within salad cultivars, 'Auriga' and 'Campari $\mathrm{F}_{1}$ ' had the highest fruit DM (6.9\%), and the fruit of both cultivars also contained a relatively high TSS (5.5 and 6.1 ${ }^{\circ}$ Brix, respectively) and TPC (160.8 and $158.1 \mathrm{mg}$ GAE $100 \mathrm{~g}^{-1}$, respectively). The highest TA $(0.65 \%)$ was measured in 'Green Zebra'. In cocktail cultivars, 'Benarys Gartenfreude' yielded the highest DM, TSS, and TA $\left(10.4 \%, 8.3^{\circ}\right.$ Brix, and $0.55 \%$, respectively). The highest TPC (275.6 mg GAE $\left.100 \mathrm{~g}^{-1}\right)$ was detected in the fruit of 'Goldita'. The fruit colour was less variable because the fruit of most cultivars was red $\left(a^{*}>10\right)$, except salad cultivar 'Green Zebra' and cocktail cultivar 'Black Cherry' (Figure 2, Table 3). In addition to the abovementioned positive correlation between fruit and leaf $\mathrm{Mg}$, a positive correlation was also found between fruit $\mathrm{Mg}$ and TA (Figure 3B) and TPC (Figure 3C) in salad cultivars. Even though we could not observe these significant relationships in cocktail cultivars, 'Supersweet 100 F $_{1}$ ', 'Primabella', 'Resi', and 'Goldita' were identified as superior cultivars in the trait combinations of fruit $\mathrm{Mg}$, 
TSS, and TPC. These cultivars had the potential for improved fruit quality under organic low-input management.

\subsubsection{Correlation between Fruit Yield and Quality}

The correlation between fruit yield and quality was analysed to determine whether the variations in fruit quality characteristics were associated with yield and fruit minerals. Pearson's correlation analysis revealed that fruit yield was negatively correlated with fruit minerals $(\mathrm{P}, \mathrm{K}, \mathrm{Mg}$, and $\mathrm{S}$ ) and quality characteristics (TSS, TA, and TPC) in salad cultivars (Figure 4A). In cocktail cultivars, significantly negative relationships were observed only between fruit yield and fruit $\mathrm{P}, \mathrm{Mg}$, and S (Figure 4B). These results imply a trade-off between fruit yield and quality at different magnitudes. In both salad and cocktail cultivars, a positive correlation was identified among fruit mineral concentrations $(\mathrm{P}, \mathrm{K}, \mathrm{Mg}$, and $\mathrm{S})$, suggesting synergistic effects of mineral allocation in fruit.

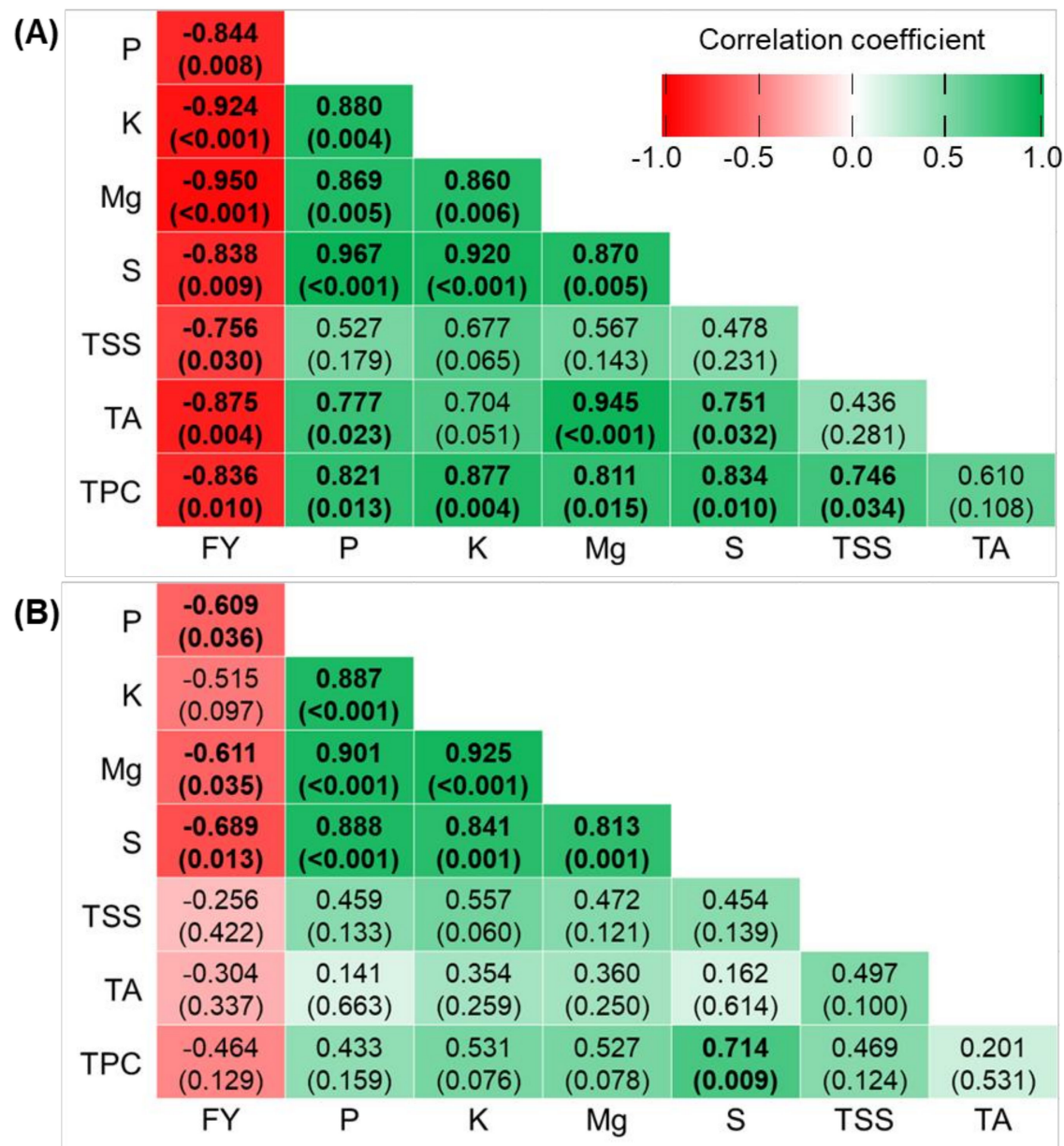

Figure 4. Pearson's correlation coefficient and $p$-values (in parentheses) among fruit quality traits of salad ((A), $n=8)$ and cocktail ((B), $n=12)$ tomato cultivars in 2015 and 2016. Values in bold are significant at $p<0.05$. FY = fruit yield; $\mathrm{P}=$ phosphorus; $\mathrm{K}=$ potassium; $\mathrm{Mg}=$ magnesium; $\mathrm{S}=$ sulphur; TSS $=$ total soluble solid; TA $=$ titratable acidity; TPC $=$ total phenolic concentration.

\section{Discussion}

The growing system used in our study can be characterised as a well-ventilated indoor or covered outdoor. The use of a rainout shelter successfully limited the presence of major pathogens that restrict indoor and outdoor tomato production. Even though it is wellknown that tomato fruit provides numerous health benefits for humans, there is a lack of breeding programmes for nutritional quality traits of the tomato [26]. Information on genotypic variation in plant morphology and fruit quality is important for producers and 
breeders to identify cultivars for production and resources in breeding programmes for improved yield and fruit quality under organic low-input management. In the present study, a diverse set of 60 tomato cultivars was first screened in 2015, and then a subset of 20 potential cultivars in plant morphology, agronomic, and fruit quality traits were selected for further evaluation in 2016. The organic low-input conditions in the present study were similar to the description of Fess et al. [27]. From the results of a two-year evaluation of these 20 cultivars, cultivars superior for fruit yield and quality traits were finally identified.

\subsection{Genotypic Variability of 60 Tomato Cultivars}

Morphological and biochemical approaches were employed to characterise $60 \mathrm{cul}-$ tivars under organic low-input management. The variations of 28 traits were similar to or higher than those found in previous studies that tested tomato cultivars in organic outdoor conditions [28], conventional plastic greenhouses [26], and conventional outdoor conditions [29]. The lower variation of some traits reported in these studies could have been caused by a smaller number of cultivars used in the trials. In addition to these reports, this study provided the first evidence of tomato panels consisting of very diverse average fruit weight, fruit numbers per plant, and leaf and stem biomass under rainout shelters in organic low-input conditions (Table 1 and Table S3). These traits are considered the main drivers for fruit yield variation in tomato $[29,30]$. The harvest index of the cultivars in our study ( 0.37 to 0.87 ) exceeded the range reported by Jones [31]. The wide range of variation in these traits determined the final use of these cultivars. Since average fruit weight plays an important role in determining fruit yield and quality [30], it was necessary to separately characterise the tomato cultivars into salad and cocktail groups in our study. The positive correlation between year of release with fruit yield, harvest index, and leaf mineral concentration of salad cultivars indicated that breeding for yield improvement in large-fruited tomato has been successful. Similar to our findings, Barrios-Masias and Jackson [29] and Higashide and Heuvelink [32] also reported a significant increase in fruit yield of tomato cultivars released over the last 50 years, which could be caused by enhanced fruit set, harvest index, and leaf photosynthetic capacity. Superior cultivars were derived from very different breeding backgrounds (Table S2). Salad tomato cultivars with superior performance, particularly yield and harvest index, were mainly derived from recent breeding for intensive indoor production. High-yielding cocktail cultivars were mainly derived from organic and outdoor breeding programmes. Many of the cultivars, such as 'Primabella', 'Primavera', and 'Resi', that stand out with important traits for organic low-input production were selected in organic outdoor breeding programmes. Details about the breeding background are shown in Table S2. This emphasises the importance of selection in conditions with suboptimal climates and limited nutrient supply. From producer and consumer perspectives, 20 cultivars were selected for further evaluation in 2016. The selection was on leaf and stem biomass, fruit yield, TSS, and TA, in which two to five superior cultivars in each trait were selected.

\subsection{Morphological and Fruit Quality Characterisation of the 20 Selected Cultivars}

In both years of evaluation, salad cultivars had better performance in growth and fruit yield, but their fruit quality was lower than that of cocktail cultivars (Figure S4). Similar trends were also observed by Zörb et al. [28], who evaluated 24 tomato cultivars and breeding lines under outdoor conditions. The higher leaf and stem biomass of cocktail compared with salad cultivars was caused by its greater plant height and leaf number [33]. Salad cultivars have been mainly bred for improved fruit yield and harvest index [29,34]. The absorbed mineral nutrients of these cultivars are allocated to the leaves for photosynthesis and to the fruit for yield formation. Nevertheless, fruit mineral concentrations and values of other quality characteristics are lower in salad cultivars than in cocktail cultivars, which could be caused by a dilution effect or lower mineral uptake. Such effects commonly occur when selective breeding successfully increases crop yield [35]. Moreover, fruit quality traits might be considered less important in breeding for salad cultivars compared to cocktail 
cultivars $[28,34]$. Consumer preference for cocktail tomatoes has increased because of their attractive visual appearance and enhanced taste and aroma [13,36].

Considering genotypic differences between salad and cocktail cultivars, high variations in plant growth and fruit quality characteristics were also observed in both years of evaluation (Tables 2 and 3). These variations provided the opportunity to further select cultivars with superior yield and fruit quality. Our results imply that improved growth does not necessarily result in higher fruit yield, but leaf mineral concentration remains an important factor because it is an indicator of plant nutritional status [37,38]. Average fruit weight is an important determinant of fruit yield. Fruit yield can be enhanced by increasing the average fruit weight, but the trade-off between average fruit weight and fruit number per plant should be minimised [29]. In organic farming, $\mathrm{N}$ and $\mathrm{P}$ are considered limiting nutrients for plants $[5,39]$. However, if we accept the optimal leaf $\mathrm{N}: \mathrm{P}$ ratio to be between 14:1 and 16:1 [40], the plant growth of many cultivars was not restricted in our study by the availability of these mineral nutrients in the soil, although the soil $\mathrm{N}$ concentration was lower in 2016 compared to 2015 in the early growing season (Table S1). This low soil $\mathrm{N}$ in 2016 may have reduced-but not limited-leaf and stem biomass (Table 2). Nevertheless, the fruit yield of salad cultivars was less affected, while the fruit yield of cocktail cultivars was higher in 2016 than in 2015. The difference in fruit yield of cocktail cultivars in both years may be caused by plant adaptation to modulate dry matter allocation to fruit. Additionally, 'Green Zebra', 'Tastery F1', and 'Primabella' had relatively high leaf $\mathrm{N}$ and $\mathrm{P}$ concentrations (Table 2). Potential $\mathrm{N}$ and $\mathrm{P}$ uptake by these cultivars may be enhanced by better root architecture and its response to mycorrhizal and plant growth-promoting rhizobacteria associations [41,42], which become important with inadequate $\mathrm{N}$ and $\mathrm{P}$ availability in the soil.

It remains questionable whether high mineral concentrations in leaves also contribute to enhanced mineral concentrations in fruit. Therefore, a correlation analysis of minerals in leaves and fruit was conducted. Interestingly, the results showed that salad cultivars with high $\mathrm{Mg}$ in leaves also contained high $\mathrm{Mg}$ in fruit. Moreover, fruit Mg also positively correlated with fruit TA and TPC (Figure 3). These findings highlight the importance of $\mathrm{Mg}$ in improving tomato fruit quality, which has thus far been underestimated in organic low-input conditions. In recent decades, greater emphasis has been placed on the balance of $\mathrm{N}, \mathrm{P}$, and $\mathrm{K}$ for improved crop production in organic farming because of the high rates of export from the farm, but their availabilities in the soil are frequently relatively low [43]. However, there are only a few studies on the improvement of soil-exchangeable $\mathrm{Mg}$ in organic crop production. From a broader point of view, $\mathrm{Mg}$ plays an important role in photosynthesis and the transport of photoassimilates from source to sink organs [44]. Wang et al. [45] reported that sufficient $\mathrm{Mg}$ supply increased leaf $\mathrm{Mg}$ by $34.4 \%$ and vegetable yield by $8.9 \%$, indicating that $\mathrm{Mg}$ is an efficient nutrient to improve crop yield compared to the application of other nutrients. Kashinath et al. [46] found a tomato yield increase from 7.7 to $17.9 \mathrm{t} \mathrm{ha}^{-1}$ because of optimum $\mathrm{Mg}$ application under conventional production. With respect to food quality, the $\mathrm{Mg}$ concentration in vegetables has significantly declined over the past 50 years [47]. Dietary Mg deficiency poses a major problem in the world [48] and has been associated with cardiovascular diseases [47]. High $\mathrm{Mg}$ concentration in tomato fruit also contributes to enhanced $\mathrm{Mg}$ intake for consumers. Positive correlations were also observed between fruit $\mathrm{Mg}$ and fruit $\mathrm{P}, \mathrm{K}$, and $\mathrm{S}$ in both cocktail and salad cultivars (Figure 4), suggesting that increased accumulation of $\mathrm{Mg}$ also results in high $\mathrm{P}, \mathrm{K}$, and $\mathrm{S}$ in fruit due to the balance of these minerals in the soil $[49,50]$. The positive relationship between fruit Mg with TA and TPC indicates the contribution of Mg towards enhancing the flavour and nutritional quality of tomato fruit. This contribution could be explained by improved carbohydrate transport from leaves to fruit, which is facilitated by $\mathrm{Mg}$ nutrition [48,51]. Promising cultivars for one or a combination of leaf $\mathrm{Mg}$, fruit $\mathrm{Mg}$, $\mathrm{TA}$, and TPC traits are the salad cultivars 'Auriga', 'Green Zebra', and 'Supersweet $100 \mathrm{~F}_{1}$ ', as well as the cocktail cultivars 'Primabella', 'Resi', and 'Goldita'. 


\subsection{Trade-Offs between Yield and Fruit Quality}

Negative correlations were observed between fruit yield and quality traits in salad and cocktail cultivars (Figure 4). The results implied a trade-off between achieving a high yield and improved fruit quality. Similar tendencies were also observed by Zörb et al. [28]. The negative correlations were stronger in salad than in cocktail cultivars, suggesting possibilities for improvement of fruit yield and quality in cocktail cultivars. The same task is very challenging in salad cultivars. Despite that there has been little improvement in the quality of salad cultivars, greater emphasis is at present being placed on improving these traits, e.g., sugar concentration, due to a growing awareness that taste and flavour are determinant aspects of tomato marketability [52]. Cocktail cultivars are usually consumed fresh; therefore, fruit quality traits, such as TSS and TA, have become important. This information is crucial for producers, enabling the selection of suitable cultivars (Table 4) based on marketing targets. For breeders, there is potential to cross salad and cocktail cultivars based on breeding objectives [28]. Therefore, the characterisation of salad and cocktail cultivars provides an outlook for organic breeding programmes for improved tomato yield and fruit quality.

Table 4. Cultivars with one or more superior traits under organic low-input management.

\begin{tabular}{|c|c|c|c|c|c|c|c|c|c|}
\hline Cultivar & LSB & $\begin{array}{l}\text { Fruit } \\
\text { Yield }\end{array}$ & $\begin{array}{c}\text { Leaf } \\
\mathbf{N}\end{array}$ & $\begin{array}{c}\text { Leaf } \\
\mathbf{P}\end{array}$ & $\begin{array}{c}\text { Leaf } \\
\mathrm{Mg}\end{array}$ & $\begin{array}{c}\text { Fruit } \\
\text { Mg }\end{array}$ & $\begin{array}{l}\text { Fruit } \\
\text { TSS }\end{array}$ & $\begin{array}{c}\text { Fruit } \\
\text { TA }\end{array}$ & $\begin{array}{l}\text { Fruit } \\
\text { TPC }\end{array}$ \\
\hline \multicolumn{10}{|l|}{ Salad cultivars } \\
\hline Lyterno $\mathrm{F}_{1}$ & $x$ & & & & & & & & \\
\hline Green Zebra & & & $x$ & $x$ & $x$ & $x$ & $x$ & $x$ & \\
\hline Roterno $F_{1}$ & & $x$ & & & & & & & \\
\hline Auriga $F_{1}$ & & & & & $x$ & $x$ & $x$ & $x$ & $x$ \\
\hline Campari $\mathrm{F}_{1}$ & & & & & & & & & $X$ \\
\hline \multicolumn{10}{|l|}{ Cocktail cultivars } \\
\hline Tastery $F_{1}$ & & & $x$ & $\mathrm{X}$ & & & & & \\
\hline Primabella & & & $x$ & $x$ & $x$ & $x$ & $x$ & $x$ & \\
\hline Bartelly $F_{1}$ & & $x$ & & & & & & & \\
\hline Resi & $X$ & & & & $x$ & $x$ & $x$ & $X$ & \\
\hline Supersweet $100 F_{1}$ & & & & & $x$ & $\mathrm{X}$ & $x$ & $\mathrm{X}$ & \\
\hline Goldita & & & & & $x$ & $x$ & $X$ & $x$ & $x$ \\
\hline
\end{tabular}

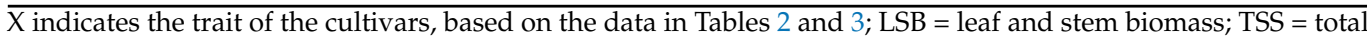
soluble solid; TA = titratable acidity; TPC $=$ total phenolic concentration .

\section{Conclusions}

Our study revealed high genotypic variability in the plant morphology and fruit quality of 60 tomato cultivars in organic low-input management. A subset of 20 cultivars was selected for further characterisation and selection of superior cultivars, which are summarised in Table 4. The different response patterns of salad and cocktail cultivars provide an outlook on improving fruit yield and quality in each group. According to this study, organic breeding has been successful for cocktail tomatoes but only to a limited extent for salad tomatoes. As an adaptation to the changed production systems, plant height, yield, and harvest index of salad tomato cultivars increased with the year of release (18802015). It is still a challenge to simultaneously improve fruit yield and quality in tomatoes of both groups. However, the information provided here is useful for producers and breeders to select superior cultivars to meet production targets and breeding objectives. Our focus on the importance of $\mathrm{Mg}$ highlights a novel path for further research on improving soilavailable $\mathrm{Mg}$ in organic tomato production to enhance fruit mineral concentration and quality in general.

Supplementary Materials: The following are available online at https: / www.mdpi.com/article /

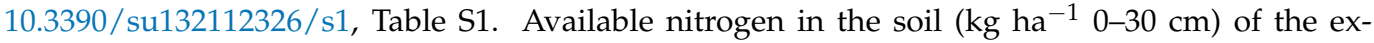
periment sites in 2015 and 2016; Table S2. Year of release, breeding background, average fruit weight, and suitable production system of 60 tomato cultivars used in Germany, Switzerland, and Austria; Table S3. Statistics for 28 traits of 60 tomato cultivars; Table S4. Analysis of vari- 
ance (ANOVA) of cocktail and salad cultivars and mean comparison between these two groups of cultivars; Figure S1. Organic low-input tomato production under a rainout shelter; Figure S2. Performance of 33 salad tomato cultivars in organic low-input production in 2015. Pearson correlations between year of cultivar release with (A) plant height, (B) leaf $C,(C)$ leaf Ca, (D) leaf $S$, (E) fruit yield, and (F) harvest index; Figure S3: Correlation among plant morphology and fruit quality traits of salad ( $n=33$, lower diagonal) and cocktail $(n=27$, upper diagonal) tomato cultivars; Figure S4. Summary of plant morphological characteristics and fruit quality of salad $(n=8)$ and cocktail $(n=12)$ cultivars grown in 2015 and 2016.

Author Contributions: Conceptualization, B.H. and E.P.; methodology, B.H. and E.P.; formal analysis, L.C.; investigation, L.C. and C.E.; resources, B.H. and E.P.; data curation, L.C. and C.E.; writingoriginal draft preparation, L.C.; writing - review and editing, all authors; visualization, L.C.; supervision, M.N., I.S., B.H. and E.P.; funding acquisition, B.H. and E.P. All authors have read and agreed to the published version of the manuscript.

Funding: This research received no external funding.

Institutional Review Board Statement: Not applicable.

Informed Consent Statement: Not applicable.

Data Availability Statement: Data from measurements are available upon request from the corresponding author.

Acknowledgments: The authors would like to thank the European Commission for providing funding for Leangsrun Chea through the Lotus Unlimited project of Erasmus Mundus program and the Software AG Foundation to support this research. We thank the Ministry of Research, Technology and Higher Education of the Republic of Indonesia (RISTEK-DIKTI) for the financial support of Cut Erika. We are grateful to Barbara Wedemeyer-Kremer for her technical assistance during the field experiment, Jonas Lange for photographing, Usman Asghar for his support in data collection, and all technical staff of the Division Quality of Plant Products for their support and guidance in laboratory works.

Conflicts of Interest: The authors declare no conflict of interest.

\section{References}

1. FAO. Crop Production Quantity by Regions. Available online: http://www.fao.org/faostat/en/\#data/QC (accessed on 9 February 2020).

2. Aldrich, H.T.; Salandanan, K.; Kendall, P.; Bunning, M.; Stonaker, F.; Külen, O.; Stushnoff, C. Cultivar choice provides options for local production of organic and conventionally produced tomatoes with higher quality and antioxidant content. J. Sci. Food Agric. 2010, 90, 2548-2555. [CrossRef] [PubMed]

3. Rosa, A.J.S.; Sala, F.C.; Cardoso, J.C. Performance and selection of tomato cultivars for organic cultivation in greenhouse. Rev. Ceres 2019, 66, 94-101. [CrossRef]

4. Stolz, H.; Stolze, M.; Hamm, U.; Janssen, M.; Ruto, E. Consumer attitudes towards organic versus conventional food with specific quality attributes. NJAS-Wagening. J. Life Sci. 2011, 58, 67-72. [CrossRef]

5. Lammerts vans Bueren, E.T.; Jones, S.S.; Tamm, L.; Murphy, K.M.; Myers, J.R.; Leifert, C.; Messmer, M.M. The need to breed crop varieties suitable for organic farming, using wheat, tomato and broccoli as examples: A review. NJAS-Wagening. J. Life Sci. 2011, 58, 193-205. [CrossRef]

6. Horneburg, B.; Myers, J.R. Tomato: Breeding for improved disease resistance in fresh market and home garden varieties. In Organic Crop Breeding; Lammerts van Bueren, E.T., Myers, J.R., Eds.; Wiley-Blackwell: Chichester, UK; Ames, IA, USA, 2012; pp. 239-249. ISBN 9781119945932.

7. Schouten, H.J.; Tikunov, Y.; Verkerke, W.; Finkers, R.; Bovy, A.; Bai, Y.; Visser, R.G.F. Breeding has increased the diversity of cultivated tomato in the Netherlands. Front. Plant Sci. 2019, 10, 1606. [CrossRef] [PubMed]

8. Tanksley, S.D. The genetic, developmental, and molecular bases of fruit size and shape variation in tomato. Plant Cell 2004, 16 (Suppl 1), S181-S189. [CrossRef]

9. Scott, J.W.; Myers, J.R.; Boches, P.S.; Nichols, C.G.; Angell, F.F. Classical genetics and traditional breeding. In Genetics, Genomics and Breeding of Tomato; Liedl, B.E., Ed.; CRC Press: Boca Raton, FL, USA, 2013; ISBN 1578088046.

10. Kanski, L.; Naumann, M.; Pawelzik, E. Flavor-related quality attributes of ripe tomatoes are not significantly affected under two common household conditions. Front. Plant Sci. 2020, 11, 472. [CrossRef] [PubMed]

11. DeVerma, J.W.; Paterson, A.H. Genetics of Lycopersicon. In Genetic Improvement of Tomato; Kalloo, G., Ed.; Springer: Berlin/Heidelberg, Germany, 1991; ISBN 3642842771.

12. Behr, H.-C. AMI Markt Bilanz Gemüse 2019; Agrarmarkt Informations-Gesellschaft mbH: Bonn, Germany, 2019. 
13. Van Heusden, S.; Lindhout, P. Genetics and breeding. In Tomatoes: Crop Production Science in Horticulture, 2nd ed.; Heuvelink, E., Ed.; CAB International: Wallingford, UK, 2018; pp. 27-56. ISBN 9781780641935.

14. Rocha, M.d.C.; Deliza, R.; Corrêa, F.M.; Carmo, M.G.d.; Abboud, A.C. A study to guide breeding of new cultivars of organic cherry tomato following a consumer-driven approach. Food Res. Int. 2013, 51, 265-273. [CrossRef]

15. Davies, J.N.; Hobson, G.E. The constituents of tomato fruit-The influence of environment, nutrition, and genotype. Crit. Rev. Food Sci. Nutr. 1981, 15, 205-280. [CrossRef]

16. Dorais, M.; Papadopoulos, A.P.; Gosselin, A. Greenhouse tomato fruit quality. In Horticultural Reviews; Janick, J., Ed.; Wiley \& Sons: New York, NY, USA, 2001; pp. 239-319. ISBN 9780470650806.

17. Causse, M.; Friguet, C.; Coiret, C.; Lépicier, M.; Navez, B.; Lee, M.; Holthuysen, N.; Sinesio, F.; Moneta, E.; Grandillo, S. Consumer preferences for fresh tomato at the European scale: A common segmentation on taste and firmness. J. Food Sci. 2010, 75, S531-S541. [CrossRef] [PubMed]

18. Statistisches Bundesamt. Area Under Cultivation: Vegetables and Strawberries. Available online: https://www.destatis.de/EN/ FactsFigures/EconomicSectors/AgricultureForestryFisheries/FruitVegetablesHorticulture/Tables/1_1Organicfarming.html (accessed on 16 August 2018).

19. FiBL. Organic Imports to Germany. Available online: https://www.fibl.org/en/service-en/news-archive/news/article/organicimports-to-germany.html (accessed on 15 October 2019).

20. FAO. World Markets for Organic Fruit and Vegetables: Opportunities for Developing Countries in the Production and Export of Organic Horticultural Products; FAO: Rome, Italy, 2001.

21. European Council. Commission Regulation (EC) No 889/2008 of 5 September 2008 laying down detailed rules for the implementation of Council Regulation (EC) No 834/2007 on Organic Production and Labelling of Organic Products with Regard to Organic Production, Labelling and Control. Available online: http:/ / data.europa.eu/eli/reg/2008/889/2018-01-01 (accessed on 19 September 2018).

22. Rauber, R.; Schmidtke, K.; Kimpel-Freund, H. The Performance of Pea (Pisum sativum L.) and its Role in Determining Yield Advantages in Mixed Stands of Pea and Oat (Avena sativa L.). J. Agron. Crop. Sci. 2001, 187, 137-144. [CrossRef]

23. Erika, C.; Griebel, S.; Naumann, M.; Pawelzik, E. Biodiversity in tomatoes: Is it reflected in nutrient density and nutritional yields under organic outdoor production? Front. Plant Sci. 2020, 11, 589692. [CrossRef]

24. Liu, J.; Hu, T.; Feng, P.; Wang, L.; Yang, S. Tomato yield and water use efficiency change with various soil moisture and potassium levels during different growth stages. PLoS ONE 2019, 14, e0213643. [CrossRef]

25. Mohammed, A.E.; Smit, I.; Pawelzik, E.; Keutgen, A.J.; Horneburg, B. Organically grown tomato (Lycopersicon esculentum Mill.) Bioactive compounds in the fruit and infection with Phytophthora infestans. J. Sci. Food Agric. 2012, 92, 1424-1431. [CrossRef]

26. Capel, C.; Yuste-Lisbona, F.J.; López-Casado, G.; Angosto, T.; Heredia, A.; Cuartero, J.; Fernández-Muñoz, R.; Lozano, R.; Capel, J. QTL mapping of fruit mineral contents provides new chances for molecular breeding of tomato nutritional traits. Theor. Appl. Genet. 2017, 130, 903-913. [CrossRef]

27. Fess, T.L.; Kotcon, J.B.; Benedito, V.A. Crop breeding for low input agriculture: A sustainable response to feed a growing world population. Sustainability 2011, 3, 1742-1772. [CrossRef]

28. Zörb, C.; Piepho, H.-P.; Zikeli, S.; Horneburg, B. Heritability and variability of quality parameters of tomatoes in outdoor production. Research 2020, 2020, 6707529. [CrossRef] [PubMed]

29. Barrios-Masias, F.H.; Jackson, L.E. California processing tomatoes: Morphological, physiological and phenological traits associated with crop improvement during the last 80 years. Eur. J. Agron. 2014, 53, 45-55. [CrossRef]

30. Van der Ploeg, A.; van der Meer, M.; Heuvelink, E. Breeding for a more energy efficient greenhouse tomato: Past and future perspectives. Euphytica 2007, 158, 129-138. [CrossRef]

31. Jones, J.B. Tomato Plant Culture: In the Field, Greenhouse, and Home Garden; CRC Press: Boca Raton, FL, USA; London, UK, 1999; ISBN 0-8493-2025-9.

32. Higashide, T.; Heuvelink, E. Physiological and morphological changes over the past 50 years in yield components in tomato. J. Amer. Soc. Hort. Sci. 2009, 134, 460-465. [CrossRef]

33. Van der Ploeg, A.; Heuvelink, E. Influence of sub-optimal temperature on tomato growth and yield: A review. J. Hortic. Sci. Biotechnol. 2005, 80, 652-659. [CrossRef]

34. Causse, M.; Saliba-Colombani, V.; Lecomte, L.; Duffe, P.; Rousselle, P.; Buret, M. QTL analysis of fruit quality in fresh market tomato: A few chromosome regions control the variation of sensory and instrumental traits. J. Exp. Bot. 2002, 53, 2089-2098. [CrossRef]

35. Davis, D.R. Declining fruit and vegetable nutrient composition: What is the evidence? HortScience 2009, 44, 15-19. [CrossRef]

36. Piombino, P.; Sinesio, F.; Moneta, E.; Cammareri, M.; Genovese, A.; Lisanti, M.T.; Mogno, M.R.; Peparaio, M.; Termolino, P.; Moio, L.; et al. Investigating physicochemical, volatile and sensory parameters playing a positive or a negative role on tomato liking. Food Res. Int. 2013, 50, 409-419. [CrossRef]

37. Kirkby, E. Introduction, definition and classification of nutrients. In Marschner's Mineral Nutrition of Higher Plant, 3rd ed.; Marschner, P., Ed.; Academic Press: San Diego, CA, USA, 2012.

38. Huett, D.O.; Maier, N.A.; Sparrow, L.A.; Piggott, T.J. Vegetable crops. In Plant Analysis: An Interpretation Manual, 2nd ed.; Reuter, D.J., Robinson, J.B., Dutkiewicz, C., Eds.; CSIRO Pub: Colingwood, Australia, 1997; pp. 383-464. ISBN 0643059385. 
39. Nasiyev, B.; Vassilina, T.; Zhylkybay, A.; Shibaikin, V.; Salykova, A. Physicochemical and biological indicators of soils in an organic farming system. Sci. World J. 2021, 2021, 9970957. [CrossRef] [PubMed]

40. Abduelghader, A.A.; Sanders, F.E.; Pilbeam, D.J. Growth and biomass partitioning in tomato in relation to ratio of nitrogen:phosphorus supply. J. Plant Nutr. 2011, 34, 2018-2038. [CrossRef]

41. Raklami, A.; Bechtaoui, N.; Tahiri, A.-I.; Anli, M.; Meddich, A.; Oufdou, K. Use of rhizobacteria and mycorrhizae consortium in the open field as a strategy for improving crop nutrition, productivity and soil Fertility. Front. Microbiol. 2019, 10, 1106. [CrossRef] [PubMed]

42. Gamalero, E.; Trotta, A.; Massa, N.; Copetta, A.; Martinotti, M.G.; Berta, G. Impact of two fluorescent pseudomonads and an arbuscular mycorrhizal fungus on tomato plant growth, root architecture and P acquisition. Mycorrhiza 2004, 14, 185-192. [CrossRef]

43. Goulding, K.; Stockdale, E.; Watson, A.C. Plant nutrients in organic farming. In Organic Crop Production: Ambitions and Limitations; Kirchmann, H., Bergström, L., Eds.; Springer: Dordrecht, The Netherlands, 2008; ISBN 9781402093159.

44. Koch, M.; Busse, M.; Naumann, M.; Jákli, B.; Smit, I.; Cakmak, I.; Hermans, C.; Pawelzik, E. Differential effects of varied potassium and magnesium nutrition on production and partitioning of photoassimilates in potato plants. Physiol. Plant. 2019, 166, 921-935. [CrossRef]

45. Wang, Z.; Hassan, M.U.; Nadeem, F.; Wu, L.; Zhang, F.; Li, X. Magnesium fertilization improves crop yield in most production systems: A meta-analysis. Front. Plant Sci. 2019, 10, 1727. [CrossRef] [PubMed]

46. Kashinath, B.L.; Murthy, A.N.G.; Senthivel, T.; Pitchai, G.J.; Sadashiva, A.T. Effect of applied magnesium on yield and quality of tomato in Alfisols of Karnataka. J. Hortic. Sci. Biotechnol. 2013, 8, 55-59.

47. Rosanoff, A. Changing crop magnesium concentrations: Impact on human health. Plant Soil 2012, 368, 139-153. [CrossRef]

48. Cakmak, I. Magnesium in crop production, food quality and human health. Plant Soil 2013, 368, 1-4. [CrossRef]

49. Weih, M.; Hamnér, K.; Pourazari, F. Analyzing plant nutrient uptake and utilization efficiencies: Comparison between crops and approaches. Plant Soil 2018, 430, 7-21. [CrossRef]

50. Hawkesford, M.; Horst, W.; Kichey, T.; Lambers, H.; Schjoerring, J.; Møller, I.S.; White, P. Functions of macronutrients. In Marschner's Mineral Nutrition of Higher Plant, 3rd ed.; Marschner, P., Ed.; Academic Press: San Diego, CA, USA, 2012.

51. Bertin, N.; Génard, M. Tomato quality as influenced by preharvest factors. Sci. Hortic. 2018, 233, 264-276. [CrossRef]

52. Beckles, D.M. Factors affecting the postharvest soluble solids and sugar content of tomato (Solanum lycopersicum L.) fruit. Postharvest Biol. Technol. 2012, 63, 129-140. [CrossRef] 